\title{
PENINGKATAN PENGETAHUAN DAN KETERAMPILAN GURU SD MUHAMMADIYAH 4 BATU DALAM MENGELOLA PEMBELAJARAN ABK MELALUI LESSON STUDY
}

\author{
Endang Poerwanti, Siti Fatimah S., Arina Restian. \\ FKIP Universitas Muhammadiyah Malang \\ email: endangpoer@yahoo.com
}

\begin{abstract}
ABSTRAK
Anak-anak dengan kebutuhan khusus (ABK) yang dikenal sebagai anak-anak cacat, atau anak-anak yang luar biasa, anak-anak yaitu yang menyimpang secara signifikan dari kriteria normal, baik dari aspek fisik, psikologis, emosional dan sosial. Mulai tahun 2001, pemerintah mulai program pendidikan inklusif, pendidikan inklusif adalah untuk memasukkan anak-anak dengan kebutuhan khusus belajar bersama dengan anak normal di kelas dan sekolah reguler. Masalahnya, guru di sekolah reguler tidak berpendidikan dan dipersiapkan khusus untuk mengelola proses belajar mengajar untuk ABK. Masalah juga dialami oleh SD Muhammadiyah 4 Batu, untuk membantu memecahkan masalah tim FKIP menerapkan aktivitas Lesson Study untuk meningkatkan pengetahuan guru dan keterampilan dalam mengelola ABK pembelajaran individual Lesson study yang dilakukan dalam tiga siklus yang dikemas dalam tiga model pembelajaran; ABK belajar sendiri di kelas khusus, pengajaran dan pembelajaran di kelas reguler dan pengajaran dan pembelajaran $A B K$ di kelas reguler dengan bantuan GPK. Setiap siklus terdiri dari beberapa kegiatan. Studi pelajaran terdiri dari empat kegiatan yang disingkat PDCA; P (rencana) atau perencanaan, D (lakukan) adalah pelaksanaan pembelajaran oleh seorang guru sebagai model dan diamati oleh guru lainnya, C (cek) merupakan cerminan dari perbaikan lebih lanjut proses pembelajaran, dan A (tindak) adalah tindak lanjut.

Dari tiga tahapan pelaksanaan proses belajar mengajar ABK dapat memberikan manfaat bagi para guru untuk meningkatkan pemahaman dan keterampilan untuk mengelola pembelajaran untuk ABK. Melalui Lesson Study diharapkan ABK mendapatkan layanan yang tepat dan belajar yang optimal. Beberapa temuan dampak pada perilaku siswa di kelas adalah bahwa siswa dapat menerima keberadaan ABK di. Meskipun keterbatasan kelas fasilitas guru mendapatkan pengalaman berharga yang terkait dengan pengembangan pembelajaran melalui forum ABK Lesson Study. Jadi kebutuhan untuk pelaksanaan tindak lanjut di kelas lain. Bimbingan dan bantuan dari Universitas Muhammadiyah untuk pergi ke SD Muhammadiyah Batu untuk menjadi sekolah mandiri.
\end{abstract}

Kata kunci: ABK, pengajaran dan pembelajaran, Lesson Study

\begin{abstract}
Children with special needs (ABK) also known as children with disabilities, or exceptional children, i.e. children who deviate significantly from the normal criteria, both from the physical, psychological, emotional and social aspect. In 2001, the government started the inclusive education programs to include children with special needs to learn together with normal children in the regular classroom and school. The problem is, teachers in regular schools are not specifically trained and prepared to manage teaching and learning for ABK. This kind of problems were also experienced by SD Muhammadiyah 4 Batu. In solving the problems, the team from FKIP implemented Lesson Study activities to improve the teachers' knowledge and skills in managing ABK individual learning.
\end{abstract}


Lesson study, conducted in three cycles, were packaged in three learning models; ABK individual learning in a special class, the teaching and learning in the regular classroom, and teaching and learning for $\mathrm{ABK}$ in the regular class with the assistance of classroom teacher assistant (GPK). Each cycle consists of several activities. Lesson study is composed of four activities that abbreviated PDCA; P (plan) or planning, D (do) is the implementation of learning by one teacher as a model and observed by other teachers, $C$ (check) is a reflection of the learning process for further improvement, and A (Act) is the follow-up activities.

The three stages of the implementation of ABK teaching and learning can provide benefits for teachers to improve the understanding and skills in managing the learning activities for the ABK. Lesson study is expected to provide the ABK with proper service and optimal learning activities. Some of the findings on the impact of student behavior in the classroom are that students can accept the existence of ABK. Despite the limitations of the class facilities, teachers are having valuable experiences in relation with the development of learning through ABK Lesson Study forums as the need for the follow-up implementation in another class. Guidance and assistance from the University of Muhammadiyah are provided to design SD Muhammadiyah Batu in becoming an independent inclusion school.

Keywords: $A B K$, teachings and learning, Lesson Study

\section{PENDAHULUAN}

Standar kompetensi profesional guru kelas SD-MI yang ditetapkan Direktorat Ketenagaan, DitJen DIKTI Tahun 2006, yang juga tertuang dalam Peraturan Menteri DIKNAS Nomor 16 tahun 2007, salah satunya adalah Kemampuan memahami perbedaan individual peserta didik, baik segi kognitif, dan emosional terhadap perkembangan peserta didik, termasuk pengenalan perkembangan abnormal pada anak usia SD/MI, yang dalam dunia pendidikan disebut dengan Anak Berkebutuhan Khusus (ABK) dan upaya optimalisasi dalam pembelajaran. Selanjutnya PERMENDIKNAS nomor 70/2009 tentang Pendidikan Inklusif, dalam pasal 2 menyatakan pendidikan inklusif bertujuan untuk memberikan kesempatan seluas-luasnya kepada semua siswa yang memiliki kelainan fisik, emosional, mental, dan sosial, atau memiliki kecerdasan dan bakat istimewa untuk memperoleh pendidikan yang bermutu sesuai dengan kebutuhan dan kemampuannya.
Anak berkebutuhan khusus (ABK) awalnya dikenal dengan istilah anak cacat, anak berkelainan atau anak luar biasa, yang didefinisikan sebagai anak yang menyimpang dari kriteria normal secara signifikan, baik dari aspek fisik, psikis, emosi dan sosial, sehingga untuk mengembangkan potensinya diperlukan adanya layanan pendidikan khusus. Selama ini, pendidikan bagi ABK disediakan dalam tiga lembaga pendidikan, yaitu Sekolah Berkelainan (SLB), Sekolah Dasar Luar Biasa (SDLB), dan Pendidikan Terpadu. Perkembangan terbaru pemerintah menggulirkan program pendidikan inklusi yaitu, ABK dididik bersama-sama anak normal di Sekolah Reguler. Persoalan yang muncul adalah, guru-guru di SD reguler tidak dididik secara khusus untuk menghadapi siswa ABK, sehingga penyelenggaraan sekolah Inklusi menjadi persoalan tersendiri bagi guru dan sekolah.

Paradigma pendidikan inklusif yaitu sistem pemberi layanan pendidikan inklusif 
yaitu sistem pemberian layanan pendidikan dalam keberagaman, dan falsafahnya yaitu menghargai perbedaan semua anak. Pendidikan inklusif adalah sebuah paradigma pendidikan yang humanis. Pendidikan inklusif adalah sebuah falsafah pendidikan yang dapat mengakomodasi semua anak sesuai dengan kebutuhannya.

Pada tataran operasional layanan pendidikannya menggeser pola segregasi menuju pola inklusi, hal ini mengandung kensukuensi logis terhadap penyelenggaraan pendidikan di sekolah umum dan sekolah kejuruan, antara lain sekolah harus lebih terbuka, ramah terhadap anak, dan tidak diskriminatif. Permendiknas nomor 70 tahun 2009 tentang Pendidikan Inklusif, dalam pasal 10 menegaskan bahwa menjadi tanggung jawab pihak otoritas untuk menyediakan kesempatan bagi guru menerima pembinaan agar dapat menghadapi situasi yang sulit. Kenyataan kewajiban tersebut belum dilakukan secara sungguh sungguh oleh pemerintah daerah dalam hal ini Dinas Pendidikan KabupatenKota. Berbagai permasalahan dari sekolah inklusi telah terpotret lewat dua penelitian terdahulu yang telah dilakukan yaitu "Pemetaan kompetensi guru SD dalam mengelola pembelajaran di sekolah inklusi" dan "Problematika implementasi pendidikan inklusi di Sekolah Dasar”.

Kesimpulannya menyatakan bahwa secara umum guru belum memiliki kompetensi yang memadai dalam mengelola pembelajaran di sekolah inklusi yang meliputi pengetahuan dan pemahaman tentang : (1) Kemampuan asesmen awal/ diagnosis awal (2) metode pembelajaran inovatif dan kreatif sesuai kebutuhan (3) kompetensi umum dan wawasan luas tentang ABK (4) kemampuan mengembangkan PPI (5) pengenalan alat peraga (6) asesment hasil belajar ABK (7) pemahaman psikologi anak, psikologi perkembangan, dan psikologi abnormal dan perlunya pengalaman eksplorasi keunikan ABK. Penelitian Kedua kesulitan yang dialami oleh guru adalah mengenali jenis dan tingkat kelainan ABK, dan bagaimana membelajarkan ABK baik dalam perencanaan pembelajaran individual maupun pelaksanaannya.

Permasalahan umum tersebut juga dialami oleh SD Mitra yaitu SD Muhammadiyah 4 Kota Batu, ditambah adanya persoalan khusus yang mendesak untuk menangani ABK, untuk itu permasalahan ini perlu untuk segera mendapat penanganan yang berupa pembinaan dan pendampingan.

Persoalan yang dialami oleh SD Muhammadiyah 4 Kota Batu adalah bahwa, sekolah yang tergolong SD favorit dan memiliki kelas paralel masing-masing tiga rombongan belajar pada setiap kelas, dengan jumlah siswa diatas 600 (641 siswa). Sebagai sekolah yang dianggap maju, wajib menyelenggarakan pendidikan untuk ABK dan sekolah telah mulai menerima ABK mulai tahun ajaran 20122013. Tahun tersebut tercatat sebanyak 17 siswa ABK ada di kelas 1. Karena guru tidak memiliki kompetensi khsusus dalam mengelola pembelajaran untuk ABK, 17 siswa ini disatukan dalam kelas khusus yang diajar secara khusus, dengan bantuan guru khusus juga, hanya pada pelajaran tertentu siswa berkomunikasi dengan teman lain. Model ini jelas tidak sesuai dengan semangat dan paradigma pendidikan inklusi yang mengharuskan siswa ABK belajar bersama anak normal di kelas reguler. Penyelesaian permasalahan ini dicoba melalui Lesson Study, karena Lesson Study merupakan salah satu upaya untuk meningkatkan proses dan hasil pembelajaran yang dilaksanakan secara kolaboratif dan berkelanjutan oleh 
sekelompok guru. Dengan cara pemecahan masalah secara berkelompok, maka guru dapat saling bekerjasama dalam memecahkan masalah pembelajaran yang dihadapi khususnya pembelajaran ABK. Tujuan yang di harapkan dari kegiatan Lesson Study ini adalah peningkatan pengetahuan dan keterampilan guru SD Muhammadiyah 4 Batu dalam mengelola pembelajaran untuk $A B K$, hal ini akan bermanfaat dalam mengimplementasikan permendiknas dan kebijakan dinas pendidikan menyongsong pelaksanaan program "Education for All”..

\section{Anak Berkebutuhan Khusus (ABK)}

Anak Berkebutuhan Khusus adalah anak-anak yang mengalami perkembangan menyimpang secara signifikan dari kriteria normal. Rentangan anak dengan perkembangan menyimpang ditemukan dalam tiga kategori (Impairment, Handicapped dan Disability ). Dilihat dari waktu dikenali adanya ABK temporer adalah: anak yang mengalami hambatan sementara/ tidak tetap seperti: trauma akibat bencana atau kerusuhan, kesulitan konsentrasi karena sering diperlakukan dengan kasar , atau tidak bisa membaca karena kekeliruan guru mengajar, dan ABK permanen adalah: anak yang mengalami hambatan tetap seperti akibat dari kecacatan tertentu (anak penyandang cacat) yang dapat dikategorikan anak yang mengalami hambatan penglihatan, hambatan pendengaran ,hambatan kecerdasan, hambatan fisik, emosional, sosial dan atau dikarenakan kecelakaan sejak dan sesudah lahir sehingga mengalami kecacatan.

\section{Klasifikasi ABK}

Dilihat dari kelainan perkembangan yang dialami ABK dapay diklasifikasikan menjadi
1) Anak dengan gangguan fisik.

Anak dengan gangguan perkembangan phisik bisa dikelompokkan menjadi (1) Anak Tunanetra, (2)Tunarungu, (3) Tuna Daksa. anak tunadaksa bisa berupa kelainan pada sistem serebral dan kelainan pada sistem otot dan rangka, (4) Anak dengan gangguan emosi dan prilaku terbagi atas gangguan emosi dan gangguan sosial.

2) Anak gangguan intelektual terbagi atas anak tunagrahita, anak berbakat, anak lamban belajar, dan anak yang mengalami kesulitan belajar khusus.

3) Anak Autisme dikelompokkan berdasar klasifikasi berdasarkan interaksi sosial dan klasifikasi berdasarkan saat muncul kelainannya.

4) $\mathrm{ADHD} / \mathrm{GPPH}$ (Attention Deficit Hyperactivity Disorder / Gangguan dalam Pemusatan Perhatian dan Hiperaktivitas) terbagi menjadi ADHD/GPPH tipe kombinasi, ADHD/GPPH tipe kurang mampu memperhatikan, dan ADHD/GPPH tipe predominan hiperaktif-impulsif.

\section{Pendidikan Inklusi}

Program pendidikan inklusi yang digulirkan pemerintah merupakan salah satu peningkatan pelayanan pendidikan yang harus mendapatkan respon positif dari semua pihak. Inovasi dan perubahan seiring dengan berkembangnya ilmu pengetahuan dan teknologi membuat lembaga pendidikan merubah paradigma lama menuju paradigma baru. Pendidikan inklusi adalah mengikut sertakan Anak Berkebutuhan Khusus (ABK) untuk belajar bersama-sama dengan anak normal di kelas dan sekolah reguler. Pendidikan inklusi diharapkan dapat memecahkan salah satu persoalan dalam penanganan pendidikan bagi anak berkelainan.

Falsafah inklusi memandang manusia sebagai makhluk yang sederajat walaupun berbeda-beda. Falsafah inklusi mencoba 
menghargai perbedaan-perbedaan setiap individu. Inklusif memandang manusia dengan segala karakteristik uniknya, merangkul perbedaan yang ada dan saling berbagi sesama manuasi. Dalam konteks pendidikan inklusif berarti semua anak, siapapun mereka, terlepas dari kemampuan maupun ketidakmampuan mereka, latar belakang sosial-ekonomi, suku, budaya atau bahasa, agama ataupun jender selayaknya menyatu dalam komunitas sekolah yang sama (Shaeffer, 2005).

\section{Implementasi Pendidikan Inklusif}

Penempatan ABK di dalam sekolah reguler menuntut adanya beberapa penyesuaian di sekolah sehingga menjadi komunitas yang mendukung pemenuhan kebutuhan khusus ABK yaitu ; (1) Adanya guru yang profesional, ramah dan berwawasan inklusif. Guru diharapkan dapat menciptakan pembelajaran yang ramah dan merespon berbagai situasi kelas serta adanya perbedaan setiap anak. (2)ABK berada dalam kelas reguler sepanjang hari. (3) Kurikulum dan pembelajaran yang fleksibel. Penempatan ABK di dalam sekolah reguler mengharuskan sekolah inklusif perlu menyusun kurikulum yang fleksibel, (4) Lingkungan sekolah yang ramah dan mudah diadaptasi oleh semua anak dan merupakan lingkungan yang dirancang untuk semua anak dan aksesibel memberikan kenyamanan, kemudahan dan menunjang keefektifan aktifitas dan belajar selama di sekolah. (5) Adanya guru pendamping khusus bagi ABK yang bertugas yang dapat memberikan bimbingan dan pelayanan kepada anak kebutuhan khusus yang mengalami kesulitan dalam mengikuti pendidikan di sekolah reguler.

(6) Adanya pusat sumber (Resource Center) sebagai support system agar proses pendidikan berjalan dengan baik.
Salah satu poin penting adalah adanya pusat sumber. Pusat sumber adalah lembaga yang berperan membantu sekolah-sekolah inklusi yang terdekat.

Implementasi pendidikan inklusi masih banyak dilema antara dan mendukung dan menolak kebijakan ini. Namun kebijakan pendidikan inklusi telah digulirkan dengan pertimbangan bahwa (1) Belum banyak bukti empiris yang mendukung asumsi bahwa layanan pendidikan khusus yang diberikan di luar kelas reguler menunjukkan hasil yang lebih positif bagi anak; (2) Biaya sekolah khusus relatif lebih mahal dari pada sekolah umum; (3) Sekolah khusus menggunakan label berkelainan yang dapat berakibat negatif pada anak; (4) Banyak anak berkelainan tidak mampu memperoleh pendidikan karena tidak tersedia sekolah khusus yang dekat; (5) Anak berkelainan harus dibiasakan tinggal dalam masyarakat bersama masyarakat lainnya.

\section{METODE}

Metode pelaksanaan Program Lesson Study Berbasis Sekolah ini diawali dengan workshop mengenai pembelajaran ABK di Kelas I SD, dengan materi memahami perkembangan $\mathrm{ABK}$, dan jenis jenis ABK, karekteristik setiap jenis ABK dan faktor penyebabnya, bagaimana mengelola pembelajaran $\mathrm{ABK}$, dilanjutkan dengan pelatihan dan pendampingan secara intensif untuk mengembangkan RPP pada kegiatan pembelajaran yang telah disepakati. Rincian dari metode pelaksanaan Program Lesson Study berbasis sekolah adalah sebagai berikut.

1) Melakukan need asesment untuk melihat kemampuan awal guru dalam melaksanakan pembelajaran untuk ABK, serta untuk menetapkan darimana materi pelatihan akan disusun dan dilakukan 
2) Melakukan Lokakarya dengan materi utama pengenalan siapa $\mathrm{ABK}$ dan bagaimana pembelajaran untuk $\mathrm{ABK}$ serta cara menyusun rancangan pembelajaran untuk ABK.

3) Pendampingan dalam pelaksanaan Lesson Study sebanyak tiga Siklus. Setiap siklus terdiri atas 4 kegiatan yang disingkat PDCA; P (plan), D (do), C (check), dan A (act). Tahapan kegiatan dalam Lesson Study dijelaskan sebagai berikut.

(1) Perencanaan (Plan) ; Dalam tahap perencanaan, 6 orang guru kelas awal yang tergabung dalam tim Lesson study berkolaborasi untuk menyusun PPI dan RPP yang mencerminkan pembelajaran individual untuk $\mathrm{ABK}$, diawali dengan berbagi pengalaman tentang pelaksanaan pembelajaran $\mathrm{ABK}$ pada tahun ajaran sebelumnya. Hasil berbagi pengalaman dan permasalahan harus dipertimbangkan dalam penyusunan RPP, sehingga PPI/RPP menjadi sebuah perencanaan yang benar-benar matang, dalam melaksanakan pembelajaran individual untuk ABK.

(2) Pelaksanaan (Do) Pada tahapan yang kedua, terdapat dua kegiatan utama yaitu: (1) pelaksanaan pembelajaran melaksanakan pembelajaran individual untuk ABK, yang dilakukan oleh salah seorang guru yang disepakati untuk mempraktikkan PPI/RPP yang telah disusun bersama, dan (2) kegiatan pengamatan atau observasi yang dilakukan oleh anggota Tim Lesson Study.

(3) Refleksi (Check). Kegiatan refleksi dilakukan dalam bentuk diskusi yang diikuti seluruh peserta
Lesson Study, dipimpin oleh Tim Lesson Study dari UMM, kegiatan diawali dengan penyampaian kesan-kesan pengajar yang telah mempraktik-kan pembelajaran, dengan menyampaikan komentar atau kesan umum maupun kesan khusus atas proses pembelajaran yang dilakukannya, dilanjutkan dengan tanggapan dan komentar para observer dengan didukung oleh bukti-bukti yang diperoleh dari hasil pengamatan. Proses Plan berikutnya akan bergantung dari ketajaman analisis para perserta berdasarkan pengamatan terhadap pelaksanaan pembelajaran yang telah dilaksanakan.

(4) Tindak Lanjut (Act) Dari hasil refleksi dapat diperoleh sejumlah pengetahuan baru atau keputusan-keputusan penting guna perbaikan dan peningkatan proses pembelajaran, baik pada tataran individual, maupun manajerial.

\section{HASIL DAN PEMBAHASAN}

Lesson Study (LS) adalah model pembinaan (pelatihan) profesi pendidik melalui pengkajian pembelajaran secara kolaboratif dan berkelanjutan berlandaskan prinsipprinsip kolegialitas yang saling membantu dan mutual learning untuk membangun komunitas belajar. Lesson Study di SD Muhammadiyah 4 Batu, diprogram dalam 3 siklus, dengan tiga model pembelajaran $\mathrm{ABK}$, yaitu pembelajaran individual di kelas khusus, pembelajaran ABK di kelas reguler oleh guru kelas dan pembelajaran ABK dikelas reguler dengan bantuan GPK. Setiap siklus tersusun atas kegiatan. Lesson study tersusun atas 4 kegiatan yang disingkat PDCA; $\mathrm{P}$ (plan), D (do), C (check), dan A (Act). Kegiatan ini dilaksanakan bulan Oktober Desember 2014. 
Kegiatan diawali dengan need asesment untuk mengetahui kondisi dan tingkat pengetahuan awal guru tentang pembelajaran ABK. Kemudian dilakukan study banding ke SLB Pembina Lawang dan SD Inklusi percontohan untuk memberikan pengalaman bagaimana pembelajaran untuk ABK di Sekolah Luar Biasa dan pembelajaran yang dilaksanakan di Sekolah Inklusi. Secara garis besar langkah-langkah pada Lesson Study adalah Plan, Do, See. Dalam pembelajaran pada anak berkebutuhan khusus ini dilakukan selama 3 tahap. Beberapa hal yang dilakukan pada 3 tahap Lesson Study dipaparkan sebagai berikut.

\section{Siklus I}

Pada Siklus I ini pembelajaran ABK dirancang dalam setting kelas khusus, dimana satu siswa ABK akan belajar sencara individual dengan satu guru khusus

\section{a. Tahap Perencanaan (Plan)}

Perencanaan dilaksanakan hari Jum'at 31 Oktober 2014 pukul 09.30 - 11.30 WIB di SD Muhammadiyah 04 Batu yang dihadiri oleh 10 guru kelas inklusi yang tergabung dalam tim Lesson Study. Pada perencanaan kali ini Ibu Linda Yani Pusfiyaningsih, S.Psi, M.Si sebagai guru model menyusun dan menyampaikan Rencana Pembelajaran yang telah dibuat kepada peserta Lesson Study. Ada beberapa saran dari peserta dalam pembuatan RPP tersebut. Ada hal yang perlu ditambahkan dan ada beberapa hal yang perlu dihilangkan. Saran dari peserta yaitu alokasi waktu pada RPP dibuat satu kali pembelajaran saja yaitu 2x35 menit dan PPI hanya dibuat untuk pembelajaran individual, ketika siswa sudah masuk kelas reguler cukup menggunakan RPP saja. Materi yang dikembangkanmemahami angka 1-10. Dengan indikator menyebutkan angka
1 sampai 10, menyelesaikan soal hitungan 1 sampai 10, menghitung jumlah benda yang dapat mencerminkan rasa ingin tahu dan melatih kemandirian anak dalam mengerjakan tugas secara individu, dan menuliskan angka 1 sampai 10 . Guru juga mengembangkan media yang sesuai dengan tujuan pembelajaran dan kemampuan serta karakteristik siswa.

\section{b. Tahap Pelaksanaan (Do)}

Pelaksanaan (Do) tahap I dilaksanakan pada hari sabtu tanggal 1 November 2014 pukul 09.30 - 10.40. Dalam pelaksanaan pembalajaran di kelas (do), pembelajaran dilaksanakan secara Individu dengan siswa yang bernama DSI siswa kelas 1 SD Muhammadiyah 4 Batu. Data siswa yang menjadi subyek pembelajaran individual ini termasuk dalam grade $\mathrm{V}$ dengan kategori Defective (Kemampuan mental dan intelektual di bawah rata-rata dirdasarkan hasil tes CPM., ananda DSI. Dari 36 soal yang diberikan, subyek hanya benar 9 . Kelebihan yang dimiliki DSI adalah anak yang sangat mudah bersosialisasi dengan teman maupun orang di sekitarnya, mskipun dia memiliki kekurangan dalam pengucapan kalimat, namun dapat bergaul dengan cukup baik dan mampu untuk melakukan aktifitas di luar kelas seperti senam, tapak suci, ataupun olahraga yang lain.

Pembelajaran di mulai dengan memancing siswa untuk menyebutkan alat peraga yang diperlihatkan Guru. Guru menunjukkan kartu angka 1 sampai 10 dan siswa mengeja. Dalam mengeja angka siswa dapat menyebutkan secara runtut. Namun, ketika kartu angka tersebut diacak maka siswa mengalami kebingungan sehingga perlu penanaman long memory kepada siswa. Setelah Guru menunjukkan gambar disertai angka siswa dapat berhitung dengan cukup lancar karena dengan menggunakan objek gambar secara kongkret dapat 
mempermudah siswa dalam berhitung. Setelah itu Guru memberikan LKS.

Selama mengikuti kegiatan belajar perilaku yang dapat diamati dari subyek adalah sebagai berikut.

1) Konsentrasi subyek sering teralih. Hal ini juga disebabkan karena ruang khusus yang ada di sekolah masih bisa dilihat oleh anak-anak di luar ruangan sehingga mengganggu konsentrasi.

2) Subyek belum dapat membedakan angka, misalnya penulisan angka 6 seringkali terbalik.

3) Subyek belum mengenal warna, beberapa kali dicoba dengan media angka dengan warna yang berbedabeda, masih belum bisa menjawab warna dengan benar

4) Subyek juga mengalami gangguan pada pita suara, sehingga dalam berkomunikasi mengalami kesulitan, misalnya pada saat berkomunikasi pengucapan cenderung tidak jelas kadangkala tidak bermakna. Guru dan dosen pengamat yang berjumlah 8 orang diberikan lembar observasi untuk diisi selama kegiatan pembelajaran. Lembar pengamatan ini untuk digunakan sebagai bahan diskusi pada kegiatan see.

\section{c. Tahap Refleksi (See)}

Secara keseluruhan, pembelajaran yang dilaksanakan sesuai dengan Rencana Pelaksanaan Pembelajaran (RPP) yang sudah dirancang Guru sesuai yang disampaikan pada plan. Namun, masih ada beberapa hal yang perlu diperhatikan yaitu

1) Siswa belum berkonsentrasi pada saat awal pembelajaran sehingga guru harus berusaha dulu memusatkan perhatian dan mengarahkan ke benda konkret, agar siswa benar-benar siap untuk mengikuti pembelajaran.

2) Gangguan yang bersumber dari luar seperti teman yang tiba-tiba datang menghampiri dan membuat gaduh suasana kelas menyebabkan konsentrasi siswa terpecah, maka sebaiknya siswa berada dalam kelas khusus yang mana 1 kelas diisi 1 siswa. Dengan kelas khusus yang steril guru dapat memberikan terapi konsentrasi dengan cara siswa tahap demi tahap dikenalkan benda sehingga terfokus dan konsentrasinya tidak terpecah.

3) Ketika siswa belum memahami konsep yang diajarkan, sebaiknya Guru memberikan jawaban yang betul/ dibetulkan langsung pada saat pembelajaran,karena diperlukan penanaman konsep long term memory, atau bisa dilakukan dengan menirukan suara guru / penggunaan media benda yang konkret, yang biasa digunakan setiap hari dengan demikian akan membantu siswa mengingat materi yang dijarkan.

4) Hal lain yang juga perlu diperhatikan adalah pengalokasian waktu yang harus disesuaikan dengan rencana pelaksannan pembelajaran yang telah disusun agar pembelajarn dapat berjalan secara efektif.

\section{Siklus II}

Pada Siklus II ini pembelajaran ABK dirancang dalam seting kelas reguler dmana siswa ABK akan belajar bersama dengan siswa lain di kelas, dengan satu guru sebagai pengajar.

\section{a. Tahap Perencanaan (Plan)}

Pada tahap kedua guru yang berperan sebagai guru model adalah ibu Dian Kurniasih,S.Psi. Kegiatan plan dilakukan di SD Muhammadiyah 4 Batu pada hari Jum'at 7 November 2014 mulai pukul 08.15 09.45 WIB. Kegiatan plan yang dihadiri 8 Guru kelas inklusi. Pada perencanaan tahap kedua ini menyusun RPP. Materi yang 
disampaikan adalah tema 1 Diriku sub tema 2 tubuhku pada pembelajaran 3 kelas 1 . Adapun indikator yang ingin dicapai adalah siswa dapat menyebutkan berapa banyak benda menunjukkan banyak benda sesuai lambang bilangan yang ditentukan (1-5), menuliskan lambang bilangan yang sesuai dengan banyak benda, dapat mengikuti aturan dalam melakukan kegiatan, dapat menirukan membaca teks deskriptif sederhana tentang anggota tubuh, serta dapat membaca teks deskriptif sederhana tentang anggota tubuh. Ada beberapa hal yang harus ditambahkan yaitu

1) Penjelasan singkat tentang kasus, Dalam siklus ini ABK yang menjadi subyek amatan adalah anak slow learner, yang juga mengalami gangguan pendengaran dan ucapan,

2) Kriteria Ketuntasan Minimal (KKM) individual, KKM kelas, dan KKM kasus.

3) Guru disarankan untuk menggunakan media pembelajaran kartu bilangan, $\mathrm{d}$ samping benda-benda konkrit.

\section{b. Tahap Pelaksanaan (Do)}

Pelaksanaan pembelajaran dilakukan hari Sabtu, 8 November 2014 pukul 07.00- 08.10 di SD Muhammadiyah 4 Batu. Ada penggantian Guru model karena untuk membedakan model pembelajaran secara individual ataupun klasikal. Sehingga digantikan oleh Ibu Dian Kurniasih, S.Psi. Subjek dalam pelaksanaan do yang ke II ini adalah Ramzy Izza Fahrezy. Berdasarkan hasil tes CPM, Ananda Ramzy Izza Fahrezy termasuk dalam kategori intelektual dibawah rata-rata (slow learner). Latar belakang kelahiran siswa normal. Siswa menderita sakit telinga pada usia 5 tahun sampai sekarang, sehingga untuk lafal pengucapan dan pendengaran kurang jelas. Disekolah siswa termasuk anak yang aktif dan suka menggangu temannya.
Kemampuan dalam gerak motoric sangat kurang. Dalam hal akademik siswa masih perlu berlatih dalam berhitung dan menyelesaikan soal penjumlahan dan pengurangan.

Akan tetapi siswa juga kesulitan dalam membaca dan menuliskan huruf. Jika didekte perkata siswa selalu menuliskan kata per kata dan selalu ada huruf yang hilang. Misalnya "Makan" siswa hanya menuliskan "makn", "Kaki” hanya menuliskan "kai”. Pelaksanaan pembelajaran tahap II, kurang dapat berjalan secara optimal karena dalam I kelas tersebut terdapat 6 anak berkebutuhan khusus dari 15 jumlah siswa sehingga anak yang sebenarnya normal jadi terbawa suasana dan sulit dikondisikan untuk tenang dalam pembelajaran. Selain itu, ruang kelas yang tidak memungkinkan untuk dibuat kreasi pembelajaran dan juga kurangnya Guru pendamping khusus. Seharusnya dalam kelas tersebut perlu ditambahkan Guru pendamping khusus karena dalam kelas tersebut terdapat 6 anak yang berkebutuhan khusus.

\section{c. Refleksi (See)}

Secara umum pelaksanaan pembelajaran sudah sesuai dengan RPP yang telah disusun sebelumnya namun pembelajarannya kurang optimal. Dalam RPP belum tampak pembelajaran saintifik sesuai dengan karkteristik pembelajaran pada kurikulum 2013. Guru sangat sulit membuat anak berkonsentrasi karena ada 6 ABK di dalam kelas dengn ruangan yang kurang memadai, Beberapa catatan yang ada dalam siklus 2 ini adalah sebagai berikut.

1) Materi yang disampaikan walaupun sedikit akan tetapi lebih bermakna bagi siswa karena disesuaikan dengan kemampuan siswa.

2) Pembuatan dan penyiapan media dan pemberian motivasi kepada siswa, Guru sudah sangat baik. 
3) Ketika siswa sudah tidak terfokus dalam pembelajaran sebaiknya Guru harus menarik perhatian siswa misalnya memberikan permainan atau mengajak bernyanyi, dan sebagainya.

4) Pengelolaan kelas juga perlu ditingkatkan untuk mengorganisir anak ABK dan non $\mathrm{ABK}$ agar pembelajaran dapat berjalan efektif.

Pada waktu refleksi ini diberikan materi tentang bagaimana pembelajaran ABK di kelas reguler dan diputarkan film tentang contoh pembelajaran ABK dengan fasilitas dan ruangan yang ideal.

\section{Siklus III}

Pada Siklus III ini Pembelajaran ABK dirancang dalam seting kelas reguler, dimana siswa ABK akan belajar sencara individual dengan GPK (guru pendamping khusus).

\section{a. Perencanaan (Plan)}

Pada tahap III, pembelajaran ABK dilakukan di kelas klasikal dengan Guru pendamping khusus. Tahap ini diawali dengan perencanaan (plan) yang dilakukan pada hari selasa tanggal 25 November 2014 pukul 09.00 WIB - 10.30 WIB di SD Muhammadiyah 4 Kota Batu yang dihadiri oleh 9 Guru kelas inklusi. Guru model adalah Dita Ayu Maulida, dengan Materi yang disajikan adalah tema aku dan sekolahku, subtema kegiatan ekstrakurikuler PB 4. Ada beberapa hal yang harus ditambahkan dalam RPP yaitu; perlu menyampaikan tujuan pembelajaran pada awal pembelajaran, pada saat kegiatan memainkan alat musik sambil bernyanyi sebaiknya pengelolaan siswa dirancang secara berkelompok, serta menambahkan penilaian ketrampilan dan RPP dibuat untuk 1 pembelajaran serta ditambahkan keterangan penanganan untuk siswa ABK serta dalam pelaksanaan pembelajaran di kelas diperlukan Guru pendamping khusus pada siswa ABK.

\section{b. Tahap Pelaksanaan (Do)}

Pelaksanaan (Do) pembelajaran dilaksanakan pada Rabu 26 November 2014 di SD Muhammadiyah 4 Batu. Ada penggantian Guru model karena oleh Ibu Dita Ayu Maulida. Materi yang disampaikan adalah tema 4 Aku dan Sekolahku sub tema 2 kegiatan ekstrakurikulerku pada pembelajaran 4 kelas 2. Subjek pada pelaksanaan do tahap III ini adalah Keizya Adam Albino. Latar belakang kelahiran siswa normal. Siswa menderita sakit ginjal ketika berusia 5 tahun. Di sekolah siswa termasuk anak yang aktif dan suka mengganggu temannya. Kemampuan dalam melakukan gerak motoric cukup baik hanya siswa tidakpernah memperhatikan perintah dari guru. Dalam hal akademik siswa sudah dapat berhitung dan menyelesaikan soal penjumlahan dan pengurangan. Namun siswa kesulitan dalam membaca dan menuliskan huruf.

Pelaksanaan pembelajaran tahap II, kurang dapat berjalan secara optimal karena dalam kelas tersebut siswa sangat sulit untuk berkonsentrasi. Pada awal pembelajaran Guru kurang mempersiapkan pengelolaan kelas dan kurang menguasai materi. Pada saat mengajak siswa untuk bernyanyi guru tidak menghafal syair lagu sehingga mengganggu konsentrasi siswa. Kegiatan inti pembelajaran tidak bisa dilaksanakan sesuai dengan perencanaan dikarenakan masing-masing siswa memiliki perhatian pada masing-masing objek yang disukai.

\section{c. Tahap Refleksi (See)}

Secara umum pelaksanaan pembelajaran sesuai dengan RPP yang telah disusun sebelumnya namun pembelajarannya kurang optimal. Hampir $50 \%$ siswa tidak berkonsentrasi saat pembelajaran di mulai. Guru mngalami 
kesulitan dalam pengelolaan kelas karena berbagai tingkah laku siswa di dalam kelas. Guru sebaiknya juga lebih mempersiapkan diri dengan menghafal syair lagu yang akan diajarkan kepada peserta didik. Media pembelajaran juga perlu disiapkan kembali tidak harus alat musik rebana melainkan Guru bisa berinovasi menggunakan bendabenda seperti botol yang diisi dengan kacang hijau ataupun batu kecil.

RPP yang dibuat juga harus disesuaikan dengan kondisi siswa kegiatan pembelajarannya dibuat yang faktual melihat banyaknya siswa ABK yang ada pada kelas tersebut. Untuk mempermudah dalam mengorganisir siswa maka tempat duduk siswa perlu diatur agar siswa yang berada di pojok ruang kelas juga dapat diamati kegiatan pembelajarannya.

Pada saat refleksi ibu Kustiaun sebagai tenaga ahli memberikan contoh permodelan bagaimana pembelajaran yang efektif untuk ABK. Ada tiga hal yang selalu perlu diperhatikan agar ABK belajar dengan lebih maksimal di antaranya sebagai berikut

1) Penyesuaian waktu / pemilihan waktu yang tepat kapan ABK mau dan dapat belajar,

2) Penyesuaian cara,

3) Penyesuaian materi), yang relevan guna pemaksimalan ketercapaian pembelajaran.

Hasil penelitian ini dapat memberikan solusi pada sistem evaluasi penilaian pada sekolah dasar untuk mengetahui kekuatan, kelemahan, peluang, pada pendidikan SD sebagai penyelenggara pendidikan inklusi untuk memaksimalkan proses pembelajaran pendidikan anak autis.

Program Lesson Study yang dilaksanakan di SD muhammadiyah Batu, didasari pertimbangan sekolah ini adalah sekolah yang berada dibawah persyarikatan Muhammadiyah. Sekolah telah menjadi sekolah inklusi dan memiliki 30 siswa ABK, dengan klasifikasi seperti yang ada pada lampiran 1. Padahal dalam kenyataan Dinas Pendidikan Kota Batu belum memberi kan GPK yang secara khusus di SD tersebut, sehingga dalam mengelola pembelajaran untuk ABK sekolah dan guru banyak belajar sendiri. Baik melalui belajar mandiri, ikut pelatihan maupun KKG. Untuk itulah diperlukan peningkatan pengetahuan dan keterampilan bagaimana mengelola pembelajaran melalui Lesson Study. Hal ini dilakukan berdasar hasil survey awal yang mendapatkan data bahwa dalam berbagai kesempatan pelatihan belum pernah sampai pada praktek pembelajaran secara kolaborasi, sehingga Lesson Study akan memberikan pengalaman baru dalam peningkatan pengetahuan dan keterampilan dengan cara melaksanakan pembelajaran secara kolaborasi. Program Lesson Study Berbasis Sekolah dilaksanakan dalam 3 siklus yang dimulai pada akhir Oktober 2014 sampai Desember 2014.

Praktek pembelajaran pada Siklus 1 ini pembelajaran ABK dirancang dalam seting kelas khusus, pada siklus ini guru mendapatkan pengalaman dan pemahaman bagaimana satu siswa ABK belajar sencara individual dengan satu guru khusus. Dalam pelaksanaannya sudah cukup baik, semangat dan kesungguhan guru model maupun pengamat sangat bagus, permasalahannya adalah ruang khusus yang dimiliki sekolah belum memadai, baik dilihat dari volume dan desain ruangan maupun fasilitas belajarnya.

Pada Siklus II ini tim guru yang terlibat dalam Lesson Study mendapatkan pengalaman bagaimana merencanakan dan melaksanakan pembelajaran ABK dalam seting kelas reguler dimana siswa $\mathrm{ABK}$ akan belajar bersama dengan siswa lain di 
kelas, dengan satu guru sebagai pengajar. Dengan keterbatasan pengetahuan, pemahaman dan keterampilan serta fasilitas, guru model telah merencanakan dan melaksanakan pembelajaran secara maksimal berkolaborasi dengan tim telah menyusun program pembelajaran dan melaksanakannya di kelas. Kendala yang muncul adalah siswa ABK yang menjadi target pembelajaran 1 orang, ternyata di kelas tersebut ada 6 ABK dengan klasifikasi jenis ABK yang berbeda, sehingga sangat sulit untuk menyatukan perhatian siswa pada materi pembelajaran. Ditambah lagi luas ruangan kelas untuk belajar kurang memenuhi standar. Untuk itu pada waktu refleksi ditayangkan film yang menggambarkan bagaimana ruangan, fasilitas dan model pembelajaran yang ideal untuk $\mathrm{ABK}$ di kelas reguler.

Pada Siklus III pembelajaran ABK dirancang dalam seting kelas reguler, tetapi siswa ABK akan belajar sencara individual dengan GPK (guru pendamping khusus). Pembelajaran pada siklus ini dirancang secara bersama dengan sangat baik, tetapi dalam pelaksanaannya tidak maksimal, siswa $\mathrm{ABK}$ yang menjadi target dapat belajar dengan baik karena karena didampingi guru khusus, tetapi guru model sudah memulai pembelajaran sebelum kelas siap dan siswa konsentrasi. Ditambah lagi media yang berupa alat musik jumlahnya terbatas sehingga anak-anak justru berebut alat peraga tersebut. Pada saat refleksi ibu Kustiaun sebagai tenaga ahli memberikan contoh permodelan bagaimana pembelajaran yang efektif untuk ABK.

\section{SIMPULAN}

Pelaksanaan Lesson Study Berbasis Kelas yang dilaksanakan di SD Muhammadiyah IV Batu telah berjalan sesuai rencana. Guru sebagai pihak yang paling berperan dalam pembelajaran mendapat pengalaman yang sangat berharga terkait dengan pengembangan pembelajaran ABK ; Siklus I pembelajaran ABK dalam seting kelas khusus , dimana satu siswa ABK akan belajar secara individual dengan satu guru khusus, siklus II pembelajaran ABK dirancang dalam seting kelas reguler dimana siswa ABK akan belajar bersama dengan siswa lain di kelas, dengan satu guru sebagai pengajar, dan siklus III ini Pembelajaran ABK dirancang dalam seting kelas reguler, dimana siswa ABK akan belajar sencara individual dengan GPK, sehingga meningkatkan pengetahuan dan keterampilan guru dalam mengelola pembelajaran untuk ABK. Dampak terhadap perilaku siswa di kelas adalah lebih bisa menerima keberadaan ABK di kelasnya dan meningkatkan rasa syukur atas karunia sehat yang mereka miliki.

Banyaknya manfaat ini, perlu adanya tindak lanjut yang dimiplementasikan pada kelas atas ataupun sekolah lain. Kelanjutan bimbingan dari lembaga Universitas Muhammadiyah sangat diharapkan demi terwujudnya SD Muhammadiyah IV Batu sebagai sekolah inklusi yang mandiri.

\section{DAFTAR PUSTAKA}

Mulyono Abdulrahman (2003).Landasan Pendidikan Inklusif dan Implikasinya dalam Penyelenggaraan LPTK. Makalah seminar PLB Ditjen Dikti. Yogyakarta, 26 Agustus 2002.

Sudrajad, A. 2008. Lesson study untuk meningkatkan proses dan Hasil Pembelajaran. http://akhmadsudrajat. wordpress.com/2008/02/22/lessonstudy $/$.

Syamsuri, I. dan Ibrohim. 2008. Lesson study (Studi Pembelajaran). Malang: FMIPA Universitas Negeri Malang. 
Undang-Undang Republik Indonesia, Nomor: 20 Tahun 2003, tentang, SISDIKNAS

PERMENDIKNAS nomor 70 tahun 2009 tentang Pendidikan Inklusif

Smith.J David, 2006, Inklusi ; Sekolah Ramah Untuk Semua, PT. Nuansa Bandung

Undang-undang Nomor 20 tahun 2003 tentang Sistem Pendidikan Nasional.

UNESCO, 2004, Buku Pendidikan Inklusif Jilid 1 -6 ; Direktorat Pembinaan Sekolah Luar Biasa, Dit Jen Manjemen DIKDASMEN, Depdiknas, Jakarta

Vaughn,S., Bos,C.S.\& Schumn, J.S.(2000). Teaching Exceptional, Diverse, and at Risk Students in the General Educational Classroom. Boston: Allyn. 